\title{
Adherence of Dietary Modification for Patient Receiving Hemodialysis
}

\author{
Dr. Sahar A. Ali *
}

\begin{abstract}
Background and Aim: Adherences to fluid restriction and dietary and medication guidelines are essential for adequate management of hemodialysis patients. This study aimed to assess adherence of dietary modification for patient receiving hemodialysis.

Materials and Method: descriptive design study was conducted at Dialysis Center in Marjan hospital at Al- Hillah city, data was gathered by using prepared form, from the period ( December $5^{\text {th }} 2012$ to February $14^{\text {th }} 2013$ ), 90 patients 41 female and 49 male patient participated in the study.

Results: The results shows that the higher percentages of the sample 54.4\% were male between 41-51 years age group, $45.6 \%$ of the sample were hypertensive; $75.6 \%$ of them received two dialysis sessions within six hours per week. The results presented that $90 \%$ of the sample were receive detailed instructions to modify their diet from health care personnel and $51.1 \%$ of them were non adhere to decrease thirst and $75.5 \%$ of them didn't care about potassium in their diet.

Conclusion: Most of the convenient sample of the study was male, within age group (41-51) years, illiterate and married and city resident. Most of the samples were with free family health history; suffer from hypertension, not smoker. In addition, Most of them received two dialysis sessions with three hours per week. They did not visit dietitian, but they received detailed instruction to modify their diet and follow specific dietary regimen from health personnel.
\end{abstract}

Key wards: Adherence of dietary modification and hemdialysis

\section{INTRODUCTION}

End stage renal disease or irreversible chronic kidney failure occurs when at least 95\% of normal kidney functioning has been lost. Dialysis is a type of medical treatment that removes the excess water and waste from the blood. The most common form of dialysis is hemodialysis, which is performed by a machine that connects through the patient's veins to filter the blood, removing waste and excess fluid (Christensen et a.l, 2002). Most hemodialysis patients receive dialysis at a center two to three times a week for up to four hours per session. Unlike healthy kidney functioning which occurs on a continuous basis, individuals receiving hemodialysis are placed on stringent dietary and medical regimen to control the buildup of toxins and fluids in the blood (Rubin, 2007). Over 485,000 people in the United States have chronic kidney disease, a progressive kidney disease that may lead to hemodialysis. Hemodialysis involves a complex regimen of treatment, medication, fluid, and diet management (Matteson and Russel, 2010). Most dialysis patients urinate very little or not at all, and therefore fluid restriction between treatments is very important. Without urination, fluid will build up in the body and cause excess fluid in the heart, lungs, and ankles. Patients on dialysis need to get enough protein and adequate nutrition because they can become malnourished. This diet will help dialysis patients feel as good as possible. The dialysis diet controls the intake of fluid, protein, sodium, potassium, and phosphorus. The amounts of these nutrients in the diet are based on blood levels of sodium, potassium, phosphorus, calcium, albumin, and urea. These levels are measured before and immediately after a dialysis treatment (Mitch, 2007). Fluid restriction is based on the amount of urine output and weight gain between dialysis treatments. The WHO adherence project adopted definition of chronic disease: Diseases which have one or more of the following characteristics: they are permanent, leave residual disability, are caused by nonreversible pathological alteration, require special training of the patient for rehabilitation, or may be expected to require a long period of supervision, observation, or care. For patients with chronic illness, adherence to medical advice plays a vital role in survival. To manage chronic illness successfully, individuals must take responsibility for many aspects of their own treatment on a regular and long-term basis 
For adherence to occur, the patient needs to incorporate lifestyle changes and other behavior changes into their daily routines (Sabate, 2001). In 2005, over 312,000 patients were undergoing hemodialysis in the United States. Dialysis nonadherence rates range from $8.5 \%$ to $86 \%$. Dialysis therapy treatment nonadherence, including treatment, medication, fluid, and diet nonadherence, significantly increases the risk of morbidity and mortality (Matteson and Russel, 2010). Adherence is a major problem in patients with chronic kidney disease. Patients can be nonadherent with different aspects of their treatment, which includes medications, treatment regimens, and dietary and fluid restrictions. To minimize nonadherence, interventions need to focus on both patient factors and the extent to which relationships and system problems compromise the patient's ability to adhere to medication and treatment plans. There continues to be a tendency to focus on the patient as the reason for problems with adherence, ignoring other factors such as the patient-health care provider relationships and the health care system that surrounds the patient. The nurse can develop a strong relationship of support with the patient, identify barriers, and offer strategies to help patients improve adherence (Kammerer et al., 2007).

\section{MATERIALS AND METHOD}

A descriptive design was conducted at Dialysis Center in Marjan hospital in Hillah city. A purposive sample of 90 patients distributed as 49 male -41 female. Patients who admitted to Dialysis Center where accepted to participate in the study, how received dialysis sessions not less than one year. Questionnaire was prepared after comprehensive review of related literatures used as a mean of data collection; the data collection was carried out from the period of December $5^{\text {th }}$ 2012 to February $14^{\text {th }} 2013$ by using interview, all participants be fully aware of the aim and details of the study and reassured that any data pertaining to them deals confidential. Questionnaire was consisting of three parts: Part one include demographical data concerning the respondent specific characteristic: age, gender, educational level, marital status, address and occupation. Part two : extended to general information as smoking, chronic diseases, number of dialysis session per week, while part three consist of (21) items related to the patient adherence divided as the following: (3) items for patients adherence to dietary counseling, (7) items related to water consumption, adherence to protein consumption assessed with (3) items, while electrolytes consumption consists (8) items. Three Likert rating scale was used as no, sometimes and always, the levels of the scale were scored as 1 for no, 2 for sometimes and 3 for always.

Statistical analysis: Data were analyzed through applying descriptive and inferential analysis as; frequency, percentage and mean score.

\section{RESULTS}

Table(1):Distribution of Patients According to the Demographic data of the sample

\begin{tabular}{|l|c|c|}
\hline Demographic data & Frequency & Percentage \\
\hline Gender: & & \\
Male & 49 & $54.4 \%$ \\
Female & 41 & $45.6 \%$ \\
\hline Age in years: & 10 & \\
$20-29$ & 14 & $11.1 \%$ \\
$30-39$ & 29 & $32.6 \%$ \\
$40-49$ & 21 & $23.3 \%$ \\
$50-59$ & 16 & $17.8 \%$ \\
60 above to 73 & & \\
\hline Education Status: & 32 & $35.6 \%$ \\
Illiterate & 26 & $28.9 \%$ \\
Primary school & 17 & $18.9 \%$ \\
Intermediate school & 7 & $7.7 \%$ \\
Secondary school & 8 & $8.9 \%$ \\
High education & & \\
\hline Occupation : & 10 & $1.1 \%$ \\
Official work & 30 & $33.3 \%$ \\
Private work & 8 & $8.9 \%$ \\
Retired & 42 & $46.7 \%$ \\
Housewives & & \\
\hline Area of Residence & 75 & $83.3 \%$ \\
Urban & 15 & $16.7 \%$ \\
Rural & & \\
\hline Marital status & 7 & $7.7 \%$ \\
Single & 83 & $92.3 \%$ \\
Married & 0 & 0 \\
Widow & 0 & 0 \\
Divorced & & \\
\hline & & \\
\hline
\end{tabular}

Table(2):Distribution of the patients According to the family Health History and Smoking

\begin{tabular}{|l|c|c|}
\hline Chronic Illness & Frequency & Percentage \\
\hline $\begin{array}{l}\text { Family History for } \\
\text { Chronic Diseases }\end{array}$ & 22 & $24.4 \%$ \\
\hline $\begin{array}{l}\text { Free of Family History } \\
\text { for Chronic Diseases }\end{array}$ & 68 & $75.5 \%$ \\
\hline Smoker & 23 & $25.4 \%$ \\
\hline Non Smoker & 67 & $75.6 \%$ \\
\hline
\end{tabular}


Table(3): Distribution of the patients According to the Chronic Disease

\begin{tabular}{|l|c|c|}
\hline Chronic Illness & Frequency & Percentage \\
\hline Diabetes Mellitus & 11 & $12.2 \%$ \\
\hline Hypertension & 41 & $45.6 \%$ \\
\hline $\begin{array}{l}\text { Diabetesand } \\
\text { Hypertension }\end{array}$ & 7 & $7.8 \%$ \\
\hline Free of diseases & 31 & $34.4 \%$ \\
\hline
\end{tabular}

Table(4): Distribution of the Patients According to the Dialysis Session

\begin{tabular}{|l|c|c|}
\hline Items & Frequent & Percentage \\
\hline Number of Sessions $\backslash$ & & \\
Week & 17 & $18.9 \%$ \\
Three & 67 & $75.6 \%$ \\
Two & 6 & $6.5 \%$ \\
One & 90 & $100 \%$ \\
\hline Total &
\end{tabular}

Table (5): Patients Adherence to Dietary Counseling

\begin{tabular}{|c|c|c|c|c|c|c|c|c|}
\hline \multirow[b]{2}{*}{ Items } & \multicolumn{2}{|c|}{ No } & \multicolumn{2}{|c|}{ Sometime } & \multicolumn{2}{|c|}{ Always } & \multirow{2}{*}{ MS } & \multirow{2}{*}{ L } \\
\hline & $\mathbf{F}$ & $\%$ & $\mathbf{F}$ & $\%$ & $\mathbf{F}$ & $\%$ & & \\
\hline Visit dietitian to modify y diet & 80 & $88.9 \%$ & 10 & $11.1 \%$ & 0 & 0 & 1.1 & Ml \\
\hline $\begin{array}{l}\text { Receive detailed instruction to follow } \\
\text { dietary regimen from health personnel }\end{array}$ & 9 & $10.0 \%$ & 43 & $47.8 \%$ & 38 & $42.2 \%$ & 2.3 & $\mathrm{HL}$ \\
\hline $\begin{array}{l}\text { Use dietary supplement according to the } \\
\text { physician advice }\end{array}$ & 20 & $22.2 \%$ & 37 & $41.1 \%$ & 33 & $36.6 \%$ & 2.1 & HL \\
\hline
\end{tabular}

MS: Mean Score L: Level ML: Mild Level HL: High Level

Table (6): Patients Adherence to water Consumption

\begin{tabular}{|c|c|c|c|c|c|c|c|c|}
\hline \multirow{3}{*}{\begin{tabular}{|ll} 
& Levels \\
Items
\end{tabular}} & \multicolumn{8}{|c|}{$\mathrm{N}=90$} \\
\hline & \multicolumn{2}{|c|}{ No } & \multicolumn{2}{|c|}{ Sometime } & \multicolumn{2}{|c|}{ Always } & \multirow{2}{*}{ MS } & \multirow{2}{*}{$\mathbf{L}$} \\
\hline & $\mathbf{F}$ & $\%$ & $\mathbf{F}$ & $\%$ & $\mathbf{F}$ & $\%$ & & \\
\hline $\begin{array}{l}\text { Perform many methods to decreases thirst } \\
\text { feeling }\end{array}$ & 46 & $51.1 \%$ & 34 & $37.7 \%$ & 10 & $9 \%$ & 1.6 & HL \\
\hline Drink a lot of water to control your thirst & 31 & $34.4 \%$ & 39 & $43.3 \%$ & 20 & $22.2 \%$ & 1.8 & HL \\
\hline $\begin{array}{l}\text { Drink a lot of water when exposed to hot } \\
\text { weather }\end{array}$ & 31 & $34.4 \%$ & 44 & $48.9 \%$ & 15 & $16.7 \%$ & 1.8 & HL \\
\hline $\begin{array}{l}\text { Calculate the amount of water which you } \\
\text { consumed per day }\end{array}$ & 68 & $75.6 \%$ & 16 & $17.7 \%$ & 6 & $6.6 \%$ & 1.3 & ML \\
\hline Use juice as proper alternative for water & 39 & $43.3 \%$ & 44 & $48.9 \%$ & 7 & $7.7 \%$ & 1.6 & $\mathrm{HL}$ \\
\hline $\begin{array}{l}\text { Prefer to consumed beverage instead of } \\
\text { water }\end{array}$ & 61 & $67.8 \%$ & 24 & 26.6 & 5 & $5.5 \%$ & 1.3 & ML \\
\hline $\begin{array}{l}\text { Consume a glass of water when taking } \\
\text { medication }\end{array}$ & 35 & 38.9 & 40 & $44.4 \%$ & 15 & $16.7 \%$ & 1.7 & HL \\
\hline
\end{tabular}

Table (7): Patients Adherence to Protein Consumption

\begin{tabular}{|l|c|c|c|c|c|c|c|c|}
\hline \multirow{2}{*}{ Levels } & \multicolumn{2}{|c|}{ No } & \multicolumn{2}{|c|}{ Sometime } & \multicolumn{2}{|c|}{ Always } & \multirow{2}{*}{ MS } & L \\
\cline { 2 - 11 } & $\mathbf{F}$ & $\mathbf{\%}$ & $\mathbf{F}$ & $\mathbf{\%}$ & $\mathbf{F}$ & $\mathbf{\%}$ & & \\
\hline $\begin{array}{l}\text { Consume a lot of proteins without } \\
\text { limitation }\end{array}$ & 41 & $45.6 \%$ & 45 & 50.05 & 4 & $4.4 \%$ & 1.6 & HL \\
\hline $\begin{array}{l}\text { Believe that the proteins are harmful for } \\
\text { person who receive dialysis }\end{array}$ & 38 & $42.2 \%$ & 29 & $32.2 \%$ & 23 & $25.6 \%$ & 1.8 & HL \\
\hline Daily consumption of diary product & 23 & $25.6 \%$ & 59 & $65.6 \%$ & 8 & $8.8 \%$ & 1.8 & HL \\
\hline
\end{tabular}


Table (8): Patients Adherence for Electrolyte (Sodium and potassium) Consumption

\begin{tabular}{|c|c|c|c|c|c|c|c|c|}
\hline \multirow{3}{*}{$\begin{array}{ll} & \text { Levels } \\
\text { Items }\end{array}$} & \multicolumn{8}{|c|}{$\mathbf{N}=90$} \\
\hline & \multicolumn{2}{|c|}{ No } & \multicolumn{2}{|c|}{ Sometime } & \multicolumn{2}{|c|}{ Always } & \multirow{2}{*}{ MS } & \multirow{2}{*}{$\mathbf{L}$} \\
\hline & $\mathbf{F}$ & $\%$ & $\mathbf{F}$ & $\%$ & $\mathbf{F}$ & $\%$ & & \\
\hline $\begin{array}{l}\text { Sodium considers one of the important in } \\
\text { which you should consume it. }\end{array}$ & 42 & $46.6 \%$ & 36 & $40 \%$. & 12 & $13.3 \%$ & 1.7 & $\mathrm{HL}$ \\
\hline Cooked food is rich with sodium & 52 & $57.7 \%$ & 28 & $31.1 \%$ & 10 & $11.1 \%$ & 1.5 & HL \\
\hline Fresh food is rich with sodium & 55 & $61.1 \%$ & 29 & $32.2 \%$ & 6 & $6.6 \%$ & 1.5 & HL \\
\hline $\begin{array}{l}\text { Food products contain small quantity of } \\
\text { Sodium. }\end{array}$ & 51 & $56.6 \%$ & 30 & $33.3 \%$ & 9 & $10 \%$ & 1.5 & $\mathrm{HL}$ \\
\hline Use salt table to correct taste of your meal & 66 & $73.3 \%$ & 17 & $18.8 \%$ & 7 & $7.7 \%$ & 1.3 & ML \\
\hline $\begin{array}{l}\text { Prefer to use herbs and flavors instead of } \\
\text { salt to correct taste of your meal }\end{array}$ & 46 & $51.1 \%$ & 34 & $37.7 \%$ & 10 & $9 \%$ & 1.6 & $\mathrm{HL}$ \\
\hline $\begin{array}{l}\text { Can you numerate four food kind which } \\
\text { contain potassium }\end{array}$ & 75 & $83.3 \%$ & 13 & $14.4 \%$ & 2 & $2.2 \%$ & 1.1 & ML \\
\hline $\begin{array}{l}\text { You are following dietary instruction and } \\
\text { methods to decrease potassium in your } \\
\text { food }\end{array}$ & 68 & $75.5 \%$ & 17 & $18.8 \%$ & 5 & $5.5 \%$ & 1.3 & ML \\
\hline
\end{tabular}

\section{DISCUSSION}

Table 1: presented that the $54.4 \%$ of the sample were male, according to the age the highest percentage $29.6 \%$ were between $(41-51)$ years age group, while $35.6 \%$ of the sample were illiterate, while the highest percentage $46.7 \%$ were housewives, also the table shows that the $83.3 \%$ of the sample were urban area resident and $92.3 \%$ of the sample were married. The results of a cross-sectional study which employed purposive sampling design of 90 respondents shows that the compliance rates of dietary, fluid, medication and dialysis were $27.7 \%, 24.5 \%$, $66.5 \%$ and $91.0 \%$, respectively. Younger, male, working patients and those with longer duration on hemodialysis were found more likely to be non-compliant. Lacks of adequate knowledge, inadequate self-efficacy skills, forgetfulness and financial constraints were the major perceived barriers towards better compliance to fluid, dietary, medication and dialysis, respectively (Chan and Zalilah, 2012). The results in table 2: Shows that the highest percentage of the sample $68(75.5 \%)$ were with free family health history for chronic disease. While 67(75.6\%) of the sample were not smoker. While the results in table 3 presented that $41(45.6 \%)$ of the sample were with hypertension. Results of comparative study show that Hypertension prevalence in hemodiaysis patients was $53.8 \%$. Coronary heart disease and diabetes are risk factors for hypertension. An effective hypertension therapeutic strategy in hemodialysis patients must include increase time of hemodialysis, strict control of weight and prevention and treatment of others cardiovascular risk factors (García and
Ceballos, 2004). The results in table 4: revealed that $67(75.6 \%)$ of the sample were receive two dialysis sessions per week. Hemodialysis patients are asked to adhere to a very difficult treatment regimen consisting of fluid and diet restrictions, many daily medications, and, usually, 3- or 4hours hemodialysis sessions three times each week (Morgan, 2000). Regarding to the dietitian guidance and counseling table (5) presented that the highest percentage $80(88.9 \%)$ of the sample did not visit dietitian to modify their diet, while $43(47.8 \%)$ of them sometimes received detailed instruction to modify their dietary regimen from health personnel. Early nutritional intervention is thought to play a major role in the preservation of renal function and the overall wellbeing in the renal patient. In preparation for renal replacement therapy, a consultation with the renal nutritionist to establish a diet consistent with the existing diagnosis may increase the likelihood of reducing cardiovascular risk factors, preventing malnutrition and anemia, and slowing the progression of renal disease, all of which can contribute to positive patient outcomes (Moore et al., 2003). Table 6: Shows that the high percentage $75.6 \%$ of the sample used to consumed a lot of water without limitation or calculation , $51.1 \%$ of the participants did not follow special methods to decrease their thrust . A descriptive - correlational study carried out on 200 patients with renal failure and on hemodialysis, revealed that most of the patients $56 \%$ had non-adherence with fluid restrictions. A cross-sectional, descriptive, comparative and correlation study find that, Poor compliance with fluid restriction was defined as an interdialytic 
weight gain $>$ or $=2.5 \mathrm{~kg}$ (Fajardo, Gievara, and Gonzales, 2002). Patients across the Unitd States who had an average weight gain of at least $0.5 \mathrm{~kg}$ above their end-dialysis dry weight by the time the hemodialysis treatment started. Patients with chronic kidney disease who undergo hemodialysis treatment have similarities to heart failure patients in that both populations retain fluid frequently and have excessively high mortality. Removal of sodium and fluid is a predictor of mortality in hemodialysis patients, adequate fluid and sodium balance is crucial for the management of the patients who receive hemodialysis (Ate et al., 2001; Zadeh et al., 2009).Table 7: Presented that 65.6 of the sample consumed diary product daily, $56.7 \%$ of the sample believe that the protein is harmful for person receiving hemodialysis .Before starting dialysis, a low-protein diet consumed to limit the amount of waste products in the blood. When dialyses have been started, diet will include more protein. Getting the right amount of protein is important to overall health body needs the right amount of protein for: building muscle, repairing tissue, fighting infection, Protein-rich foods include: fresh meats, poultry (chicken and turkey) fish and other seafood eggs or egg whites, small servings of dairy products. Dietitian will help to plan the right amount of each protein source for good health and strength (National Kidney Foundation, 2000). Table 8: Shows that $61.1 \%$ of the sample believe that the fresh food is rich with sodium $83.3 \%$ of the convenient sample can't numerate food which contain potassium and $75.5 \%$ of the sample didn't follow dietary restriction and methods to decrease potassium in their food. The levels of phosphorus, potassium, and blood urea nitrogen were higher than expected levels in $25.5 \%, 5.5 \%$ and $4.5 \%$ of patients, respectively. In addition, there were relationships between blood urea nitrogen, serum potassium, serum phosphorus levels and interdialytic weight gain with educational status ( $\mathrm{p} \leq 0.05)$ (Peyrovi et al., 2010). Adherence is a major problem in patients with chronic kidney disease. Patients can be nonadherent with different aspects of their treatment, which includes medications, treatment regimens, and dietary and fluid restrictions. Although many lessons have been learned from adherence research, the evidence of how to modify adherence is somewhat mixed. To minimize nonadherence, interventions need to focus on both patient factors and the extent to which relationships and system problems compromise the patient's ability to adhere to medication and treatment plans. There continues to be a tendency to focus on the patient as the reason for problems with adherence, ignoring other factors such as the patient-health care provider relationships and the health care system that surrounds the patient. The nurse can develop a strong relationship of support with the patient, identify barriers, and offer strategies to help patients improve adherence (Fajardo et al., 2002).

\section{CONCLUSIONS}

According to the finding of the present study, Most of the convenient sample of the study was male, within age group (41-51) years, illiterate and married, housewives and city resident Most of the samples were with free family health history; suffer from hypertension, not smoker. In addition, Most of them received two dialysis sessions with three hours per week. They did not visit dietitian, but they received detailed instruction to modify their diet and follow specific dietary regimen from health personnel. With reference to water and electrolytes consumption and thirst management, most of the participants ignore how to decreases their thirst, they believed that sodium is important for them, did not follow the instruction to decrease potassium they consume.

\section{RECOMMENDATION}

The present study recommends that the dietitian should be consultant to plan renal diet and answer questions, using patient language, explain food frequency consumption, proper planning according to patient socioeconomic status should be designed. In addition, Patient education provided with family involvement is an important element for promoting adherence among patients receiving dialysis. It also recommends that future studies should be performed to test the efficacy of interventions to improve adherence in adult hemodialysis patients in order to utilize cognitive/behavioral intervention strategies, such as the feasibility and effectiveness of applying group-based cognitive behavior therapy to enhance adherence to hemodialysis fluid and diet restrictions.

\section{REFERENCES}

Ate, K., Nerg, G., Keven, K., Kutlay, S., Duman, N., Karatan, O., and Ertu, E. (2001). Effect of fluid and sodium removal on mortality in peritoneal dialysis patients. Kidney International. 60, 767-776.

Chan, Y., Zalilah, M., and Hii, S. (2012).Determinants of compliance 
behaviours among patients undergoing hemodialysis in Malaysia. Epub. 7(8). Retrieved from http://www.ncbi.nlm.nih.gov/pubmed/2287 $\underline{0215}$ on January 2013.

Christensen, A. J., Moran, P. J., Wiebe, J. S., Ehlers, S. L., and Lawton, W. J. (2002). Effect of behavioral self-regulation interventions on patient adherence in hemodialysis. Health Psychology, 21(4), $393-397$.

Fajardo, C., Guevara, R., Gonzáles, P. V., and Hurtado, A. (2002). Poor adherence to diet in hemodialysis: role of anxiety and depression symptoms. Nefrologia. 22(3), 244-252.

García, M., and Ceballos, M. (2004). Hypertension in hemodialysis patients in Andalucia. Nefrologia. 24(2), 149-57. [Article in Spanish]

Matteson, ML., and Russell, C. (2010). Interventions to improve hemodialysis adherence: a systematic review of randomized-controlled trials, Hemodial Int. 14(4) , 370-82.

Mitch, W. E. (2007). Chronic kidney disease, In: Goldman L, Ausiello D, Cecil Medicine. $\left(23^{\text {rd }}\right.$ ed). Philadelphia: Saunders Elsevier. Chap 131.

Kammerer, J., Garry, G., Hartigan, M., Carter, B., and Erlich, L. (2007) Adherence in patients on dialysis: strategies for success. Nephrol Nurs J. 34(5), 479-86.

Morgan, L. (2000). A decade review: methods to improve adherence to the treatment regimen among hemodialysis patients. Nephrol Nurs J. 27 (3), 299-304.

Moore, H., Reams, S.M., Wiesen, K., Nolph, K.D., Khanna, R., and Laothong, C. (2003). National Kidney Foundation Council on renal nutrition survey: pastpresent clinical practices and future strategic planning. Journal of Renal Nutrition. 3(13), 233-240.

“National Kidney Foundation, National Kidney Foundation's Kidney Disease Outcomes Quality Initiative'.(2000). Retrieved from www.kidney.org on January 2013.

Peyrovi, H., Sareban, Z., Mohebbi, N., and Rambod, M. (2010). Dietary and Fluid Adherence in Hemodialysis Patients. Iran Journal of Nursing. 23(67), 15-22.

Rubin, N. (2007).Treatment of irreversible renal failure, In: Goldman L, Ausiello D, Cecil Medicine. $\left(23^{\text {rd }}\right.$ ed). Philadelphia: Saunders Elsevier. Chap 13.

Sabate, E. (2001, June). WHO Adherence Meeting Report. Geneva: World Health Organization. Retrieved from (http://www.who.int/chp/knowledge/public ations/adherencerep.pdf) on January 2013.

Zadeh, K.K., Regidor, D.L., Koyesdy, C.P., Wyck, D.V., Bunnapradist, S., Horwich, T. B., and Fonarow, G.C. (2009). Fluid Retention Is Associated With Cardiovascular Mortality in Patients Undergoing Long-Term Hemodialysis Circulation. 119, 671-679. 